\title{
Angiomatoid Fibrous Histiocytoma: A Rare Entity with Recognized Diagnostic Pitfalls
}

\section{Anjiomatoid Fibröz Histiositom:Teşhis Tuzaklarına Sahip Nadir bir Antite}

Sameera Rashid ${ }^{1}$

Mohamed Meerasahib Kesudeen², Mohammed Abulaban ${ }^{3}$,

Adham Ammar ${ }^{4}$

${ }^{1}$ Resident Anatomical Pathology, Hamad Medical Corporation, Qatar

${ }^{2}$ Specialist Haematology Oncology

Department of Paediatrics, Hamad Medical

Corporation, Qatar

${ }^{3}$ Senior Consultant, Haematology Oncology, Department of Paediatrics, Hamad Medical Corporation, Qatar

${ }^{4}$ Consultant Histopathologist, Hamad Medica Corporation, Qatar

Geliş Tarihi/Received: 09 July 2018 Kabul Tarihi/Accepted: 04 September 2018

\begin{abstract}
Öz
Anjiomatoid Fibröz Histiyositoma (AFH), nadir görülen yumuşak doku tümörüdür. Genellikle çocuklarda ve genç erişkinlerde görülür ve düşük nüks ve metastaz oranlarına sahiptir. AFH, nüksleri rapor eden bazı çalışmalarla revize edilmeye devam etse de şimdiye kadar teşhis kriterleri belirsizliğini korumaya devam etmektedir. Nadir bir tümör olması sebebiyle de tanı genellikle gecikmektedir. Bu makalede atipik histoloji, immünprofil ve genetik test sonuçlarına sahip 10 yaşında bir erkek olguyu sunudu. Atipik görünümleri nedeniyle teşhis sürecinde Almanya Heidelberg Hastanesi ve Philadelphia Çocuk Hastanesinden fikir danışılan olgunun nihai tanısı Brigham Kadın Hastanesi tarafından doğrulandı. Bu makalede ayrıca literatür gözden geçirilerek ayırıcı tanı tartışıldı.
\end{abstract}

Anahtar Kelimeler: Anjiomatoid fibröz histiositom, yuvarlak hücreli tümör, yumuşak doku sarkomu, teşhis zorluğu, genetik test

\section{Abstract}

Angiomatoid Fibrous Histiocytoma (AFH) is a rare soft tissue tumour of indeterminate differentiation usually occurring in children and young adults with low rate of metastasis and recurrence. AFH continues to be revised with various studies reporting recurrences but up till now, the diagnostic criterion remains unclear with pathologists relying mainly on Enzinger's description and immunohistochemistry. Adding to the fact that it is a rare tumour, diagnosis usually is delayed. We present a case of a 10 year old male with AFH with atypical histology, immunoprofile and genetic testing. Opinions were sought from Heidelberg hospital Germany and Children Hospital of Philadelphia which had contrasting views regarding the diagnosis, which was finally confirmed by Brigham and Women's hospital, Boston. We review literature and discuss the possible differential diagnosis.

Key words: Angiomatoid fibrous histiocytoma, round cell tumour, soft tissue sarcoma, misdiagnosis, genetic testing

\section{INTRODUCTION}

Angiomatoid Fibrous Histiocytoma (AFH) is a rare soft tissue tumour. It mainly affects children and young adults and is believed to be of indeterminate differentiation. AFH arises from the dermis and subcutaneous tissue and mostly affects the extremities. It is histologically characterized by thick fibrous pseudo capsule, lymphoid infiltrate with follicular formation and nodules or fascicles of either spindle cells or histiocytoid cells. Pseudoangioectatic cystic spaces filled with blood and lined by tumour cells are the main feature. Immunohistochemistry is usually utilized to aid diagnosis. Classically, AFH is positive for Desmin and CD99 with variable positivity for Calponin, CD68 and EMA. Stains with Factor VIII, CD34, CD31, S100 and keratin are negative $(1,2)$.

The most common genetic abnormality is $t(2 ; 22)$ resulting in EWSR1-CREB1 fusion. Other observed gene fusions are FUS-ATF1 and EWSR1-ATF1.

\section{CASE REPORT}

We received case for consultation from a private care provider in Qatar. The case was that of a 10 -year-old boy that presented with a painful swelling on the back since 5 months. The swelling was near the dorsal spine, $2 \mathrm{~cm}$ in size on the right side, not adherent to the underlying structures. The family did not notice any increase in size of the swelling.

Excisional biopsy was done and report from the private care provider suggested soft tissue sarcoma, the differential diagnosis included Ewing/PNET (Primitive neuroectodermal tumor) and Low grade myofibroblastic sarcoma. Accompanying was report from Heidelberg Germany where the slides were sent for second Opinion. The report suggested "High grade Sarcoma, morphologically and immunohistochemical

\begin{tabular}{|c|c|}
\hline $\begin{array}{l}\text { Address correspondence to: Sameera Rashid, Resident Anatomical Pathology, Hamad Medical Corporation, } \\
\text { Qatar } \\
\text { e-mail: Srashid2@hamad.qa } \\
\text { Cite this article as: Rashid S, Kesudeen MM, Abulaban M, Ammar A. Angiomatoid Fibrous Histiocytoma: A Rare } \\
\text { Entity with Recognized Diagnostic Pitfalls. Selcuk Med J 2018;34(4): 176-179 }\end{array}$ & $\begin{array}{l}\text { Disclosure: None of the authors has a financial interest in any of the } \\
\text { products, devices, or drugs mentioned in this article. The research was } \\
\text { not sponsored by an outside organization. All authors have agreed to allow } \\
\text { full access to the primary data and to allow the journal to review the data } \\
\text { if requested. }\end{array}$ \\
\hline
\end{tabular}


phenotype favouring embryonal rhabdomyosarcoma". According to Heidelberg Hospital, it was positive for Desmin and focal positive for SMA, CD99, CD34, CD31 and S100. Stains with Pan-cytokeratin, neuroendocrine markers (synaptophysin and chromogranin), CD68 and bcl2 were negative.

We re-evaluated the sections as third opinion and a malignant soft tissue tumour was suggested. The tumour histologically exhibited short, oval spindle cells with overlapped nuclei arranged in plump fascicles and vague storiform growth pattern. Also apparent is fibrous capsule and lymphocytic infiltrate (figure 1).

Brisk mitosis with abnormal figures is present with tumour necrosis. There are also areas of pleomorphic spindle cells in desmoplastic stroma. On immunoprofiling it shows strong positivity for CD 99 and Desmin. Staining with EMA showed focal equivocal positivity while AE1/3, CD68 and $S 100$ are negative (figure 2). As per the given picture, rhabdomyosarcoma was the most probable diagnosis.

The patient then travelled to Children Hospital of Philadelphia where a diagnosis of Angiomatoid Fibrous Histiocytoma was made. Interestingly, genetic testing was also done which turned out to be negative for EWSR1-CREB fusion. Wider excision was performed, and it was clear of neoplasia.

Fifth and Final opinion was sought from Brigham and Women's Hospital Boston, which confirmed the diagnosis of Angiomatoid Fibrous Histiocytoma without further cytologic study.

Currently the patient is on regular follow up and no recurrence has been noted.

\section{DISCUSSION}

The problems encountered while dealing with a rare disease are less exposure of the doctor to the disease and the fact that the disease itself has not

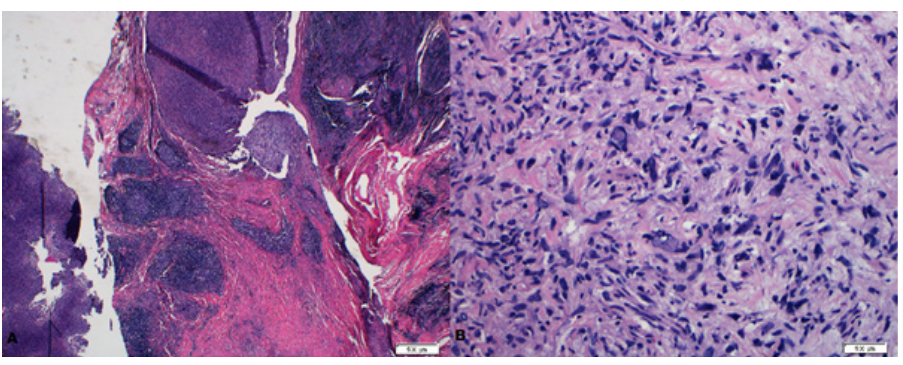

Figure 1. (A) Low power view shows the tumour capsule and lymphoid appearance (Haematoxylin and Eosin; X20). (B) Hight power view showing spindles cells in a vague fascicular pattern (Haematoxylin and Eosin; X200).

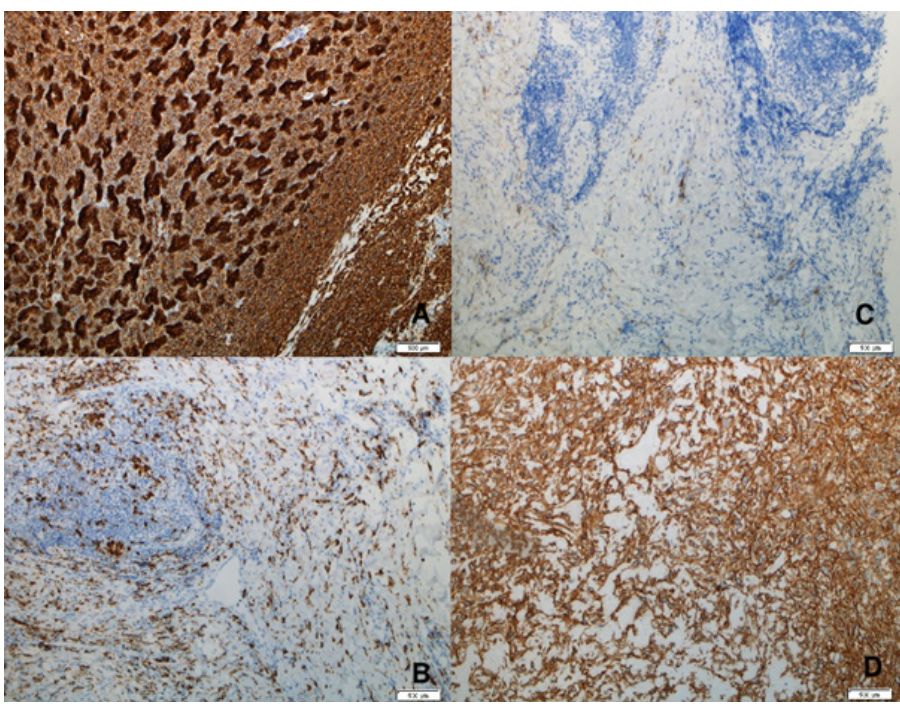

Figure 2: X40, (A): Immunohistochemistry for Desmin shows strong and diffuse staining. (B): Immunohistochemistry for EMA shows focal positive staining. (C): Immunohistochemistry for CD 68 shows no staining. (D): Immunohistochemistry for CD 99 shows strong and diffuse staining.

been studied very much because of its rarity. Thus, with a disease like AFH, which can have a histologic picture similar to sarcomas, the diagnosis and treatment is usually delayed with high possibility of misdiagnosis.

$\mathrm{AFH}$ is a rare soft tissue tumour comprising of $0.3 \%$ of all soft tissue tumours (1). It arises from the dermis and subcutaneous tissue and mostly affects the extremities. Macroscopically, AFH appears as a lymph node with hemorrhagic area and appears in areas of normal lymphoid tissue such as the antecubital fossa, axilla, inguinal and supraclavicular regions (2). Local symptoms such as pain and tenderness are not common but anemia, pyrexia and weight loss are seen in some cases suggesting release of cytokines from the neoplasm. The median age of presentation is 14 and 20 years as per two studies (3). The metastasis rate is $4 \%$ and recurrence rate is that of $12 \%$ according to one study which can be attributed to incomplete resection. Other studies report $1 \%$ metastasis rate.

$\mathrm{AFH}$ is recognized by Pseudoangioectatic cystic spaces filled with blood and lined by tumor cells. There is covering of a thick, fibrous pseudo capsule and inside are nodules or fascicles of either spindle cells or histiocytoid cells. Lymphoid infiltrate with follicular formation is also present in most cases 
(4). However, the characteristic pseudo capsule and lymphocytic infiltrate might either be absent or not present in the representative sample. Fine needle aspiration cytology is thus not recommended (5). The tumor cells are arranged in a variety of growth patterns including sheets, whirls or fascicles. There are also varieties reported with prominent myxoid matrix and schwannoma like features (6-7).

A subset of AFH has a predominantly small blue cell appearance, which can be confused with high grade undifferentiated sarcomas as was present in our patient. This subtype has dark hyperchromatic nuclei with scant eosinophilic cytoplasm mimicking Ewing sarcoma. More pleomorphic examples with brisk mitotic activity have been reported with same prognosis. This subtype is noted in only one report before (8). And it's highly likely that it is confused for small blue cell tumor especially when degree of suspicion of $\mathrm{AFH}$ is low and genetic testing is either not done or turns negative as happened in the case presented.

Immunohistochemistry is usually utilized to aid diagnosis of sarcomas. Classically, AFH is positive for Calponin, CD68, Desmin, EMA, CD99, actin. With Factor VIII, CD34, CD31, S100 and keratin, it stains negative. The most common genetic abnormality is $t(2 ; 22)$ resulting in EWSR1-CREB1 fusion which was observed in eight out of nine tumors analyzed (9). Other observed gene fusions are FUS-ATF1 and EWSR1-ATF1(10).

Rhabdomyosarcoma, on the other hand, accounts for approximately $40 \%$ of pediatric soft tissue sarcomas (11). Embryonal rhabdomyosarcoma (ERMS) comprises the single largest category of soft tissue sarcomas in children and adolescents with 4.5 cases per million persons aged $0-20$ years in USA (12). It gives a microscopic picture of primitive mesenchymal cells with stellate nuclei with sparse cytoplasm, characteristic "strap"; "tadpole cells" are present in a number of cases. Markers of skeletal muscle differentiation aid diagnosis of ERMS. In alveolar rhabdomyosarcoma, there are aggregates of poorly differentiated round cells that frequently show central loss of cellular cohesion and formation of irregular "alveolar" spaces. The cells in the center are often poorly preserved with degeneration and necrosis. Pleomorphic rhabdomyosarcoma, as another differential to AFH, was previously confused with $\mathrm{AFH}$ and is still largely differentiated with the help of immunohistochemistry. Rhabdomyosarcoma, therefore, can easily be mistaken as it also stains positive for CD99 and Desmin.

Extra skeletal Ewing sarcoma/PNET can present similar to AFH with a multilobulated soft swelling in less than $30 \mathrm{yrs}$. of age patient and hemorrhage, cyst or necrosis on cut surface. On microscopic examination it consists of uniform round cells with round nucleus, distinct nuclear membrane, fine powdery chromatin and one or two nucleoli. It has high vascularity with occasional pseudovascular or pseudoalveolar pattern caused by small fluid filled pools and thus can be mistaken for angiosarcoma, alveolar rhabdomyosarcoma or even AFH. On immunoprofiling Ewing/PNET stains positive for CD99 but not Desmin. Genetic testing for EWS gene fusion help in diagnosis as $t(11 ; 22)(q 24 ; q 12)$ is detected in $90 \%$ of the cases(13).

Other possible misdiagnoses include Nodular Kaposi with its spindle cell morphology and vascular spaces. To differentiate, the pseudoangiomatoid

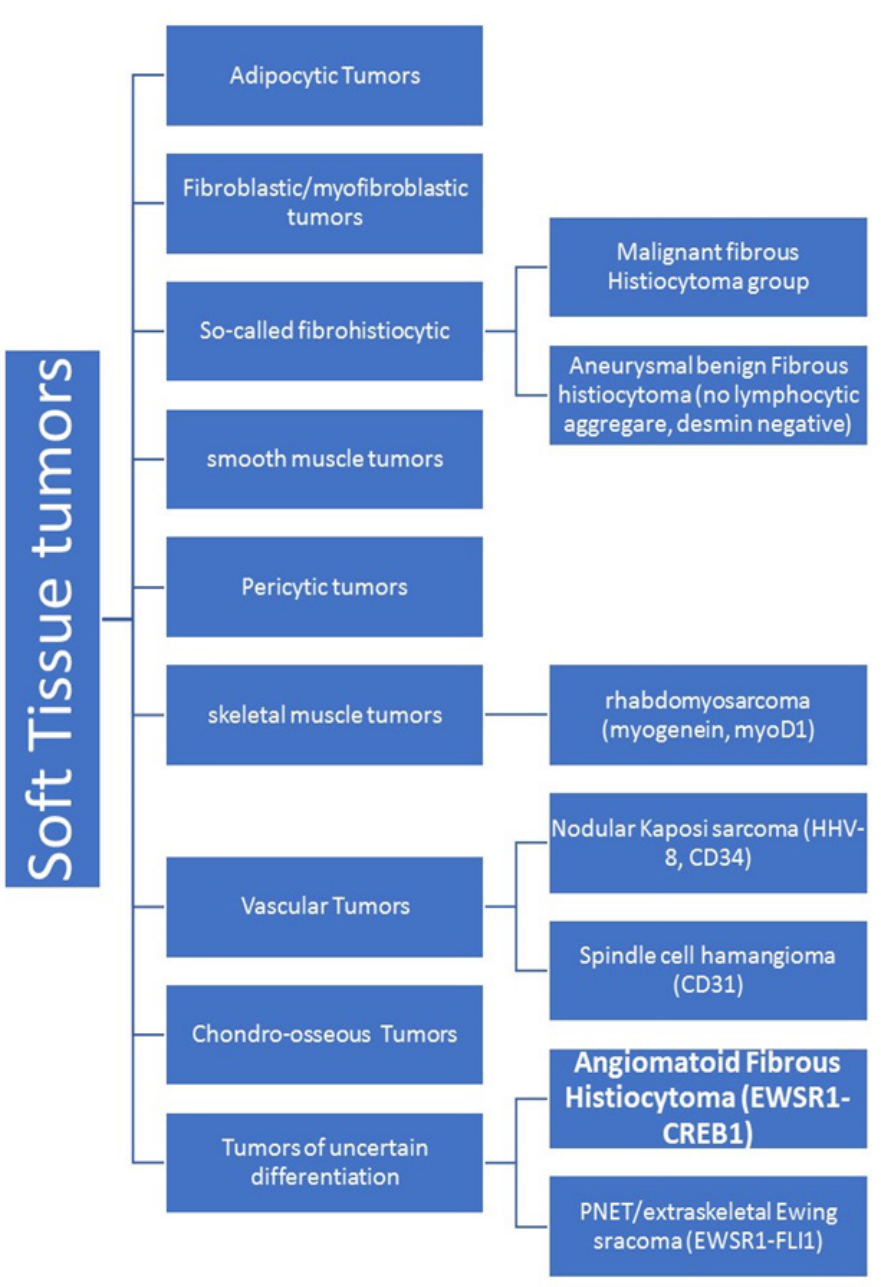


spaces in AFH are lined by flattened tumor cells and they stain negative for CD 34 and HHV8.Spindle cell hemangioma typically occurs in the dermis and subcutis of the distal extremities. It contains cavernous vascular spaces, but in contrast to AFH these are lined by an attenuated layer of endothelial cells. The bland ovoid cells of AFH can sometimes be mistaken for granulomas.

Conflict of interest: Authors declare that there is no conflict of interest between the authors of the article.

Financial conflict of interest: Authors declare that they did not receive any financial support in this study.

Address correspondence to: Sameera Rashid, Resident Anatomical Pathology, Hamad Medical Corporation, Qatar

e-mail: Srashid2@hamad.qa

\section{REFERENCES}

1. Antonescu CR, Rossi S. Angiomatoid fibrous histiocytoma in WHO classification of tumours of soft tissue and bone. 2013:204-5.

2. Fletcher $C D$. The evolving classification of soft tissue tumors: An update based on the new WHO classification. Histopathology 2006;48(1):3-12.

3. Costa MJ, Weiss SW. Angiomatoid malignant fibrous histiocytoma: A follow-up study of 108 cases with evaluation of possible histologic predictors of outcome. American J Surg Pathol1990;14:1126-3

4. Fanburg-Smith JC, Miettinen M. Angiomatoid malignant brous histiocytoma: A clinicopathologic study of 158 cases and further exploration of the myoid phenotype. Human Pathol 1999;30(11):1336-43.

5. Qian X, Hornick JL, Cibas ES, et al. Angiomatoid fibrous histiocytoma: A series of five cytologic cases with literature review and emphasis on diagnostic pitfalls. Diagnostic Cytopathol 2012;40 (supplement2):E86-93.

6. Justin Wong, SB, wee A, Puhaindran ME, et al. Angiomatoid fibrous histiocytoma with prominent myxoid stroma: A case report and review of the literature. American J Dermatopathol 2015;37(8):623-31.

7. Kao YC, Lan J, Tai HC, et al. Angiomatiod brous histiocytoma: Clinicopathological and molecular characterization with emphasis on variant histomorphology. J Clin Pathol 2014;67(3):210-5.

8. Hasegawa T, Seki K, Ono K, et al. Angiomatoid (malignant) brous histiocytoma: A peculiar low-grade tumor showing immunophenotypic heterogeneity and ultrastructural variations. Pathol Inter 2000;50(9):731-8.

9. Antonescu C. R., Dal Cin, Nafa K, et al. MEWSR1-CREB1 is the predominant gene fusion in angiomatoid fibrous histiocytoma. Genes Chromosomes. Cancer 2007;46:105160.

10. Rossi S, Szuhai K, ljszenga M, et al. EWSR1-CREB1 and EWSR1-ATF1 fusion genes in angiomatoid fibrous histiocytoma. Clinical Cancer Research 2007;13(24):7322-8.

11. Gurney JG, Young JL, Roffers SD, et al. Soft tissue sarcomas. SEER Pediatric Monograph. Bethesda, Md: National Cancer Institute, 2005.
12. Fletcher C.WHO Classification of tumors of soft tissue and bone. Lyon:IARC Press, 2013.

13. Ambros IM, Ambros PF, Strehl S, et al. MIC2 is a specific marker for ewing's sarcoma and peripheral primitive neuroectodermal tumor. Cancer 1991;67: 886-93. 